\title{
Parasitism level by helminths and weight gain of calves kept in organic and conventional grazing ${ }^{1}$
}

\author{
Jenevaldo Barbosa da Silva ${ }^{2 *}$, Gisele Maria Fagundes ${ }^{3}$, João Paulo Guimarães Soares ${ }^{4}$ \\ and Adivaldo Henrique da Fonseca ${ }^{5}$
}

\begin{abstract}
Silva J.B., Fagundes G.M., Soares J.P.G \& Fonseca A.H. 2013. Parasitism level by helminths and weight gain of calves kept in organic and conventional grazing. Pesquisa Veterinária Brasileira 33(5):586-590. Laboratório de Imunoparasitologia, Departamento de Patologia Veterinária, Facudade de Ciências Agrárias e Veterinárias, Universidade Estadual Paulista (Unesp), Via de Acesso Prof. Paulo Donato Castellane s/n, Jaboticabal, SP 14884-900, Brazil E-mail: jenevaldo@hotmail.com

Sustainable production is a principle in which we must meet the needs of the present without compromising the capacity of future generations. Despite the successful development of pesticides against endo and ectoparasites found in domestic ruminants, these parasites are still the major problem of the herbivore production system. The purpose of this study was to know the population of gastrintestinal parasites and their influence on weight gain of calves kept in organic and conventional grazing. Thus, organic and conventional calves were randomly selected in 2008 and 2009. The fecal egg count (FEC) indentified the following genders of helminths: Haemonchus, Trichostrongylus, Oesophagostomum, Cooperia, Strongyloides, Trichuris and oocysts of Eimeria. There was no significant difference ( $\mathrm{p}>0.05)$ between FEC in organic and conventional animals. Calves younger than 6 months showed significant higher infection $(\mathrm{p}<0.05)$ than calves between 7 and 12 months of age. The weight gain observed during the study was of $327 \mathrm{~g} /$ day and $280 \mathrm{~g} /$ day for conventional and organic systems animals, respectively. Consequently, the combination of sustainable practices of grazing associated with the selective application of anthelmintics may be a feasible alternative for nematode control in a conventional system and in transition to an organic one.
\end{abstract}

INDEX TERMS: Anthelmintics, eimeriosis, haemonchosis, sustainable production, cattle.

RESUMO.- [Grau de parasitismo por helmintos e ganho de peso de bezerros mantidos sob manejo orgânico e convencional.] A produção sustentável é um princípio em que devemos atender as necessidades do presente sem comprometer a capacidade das gerações futuras. No presente, apesar do sucesso no desenvolvimento de pesticidas endo e ectoparasitas de ruminantes domésticos continuam

\footnotetext{
${ }^{1}$ Received on January 21, 2013.

Accepted for publication on March 20, 2013.

${ }^{2}$ Laboratório de Imunoparasitologia, Departamento de Patologia Veterinária, Facudade de Ciências Agrárias e Veterinárias (FCAV), Universidade Estadual Paulista (Unesp), Via de Acesso Prof. Paulo Donato Castellane s/n, Jaboticabal, SP 14884-900, Brazil. *Corresponding author: jenevaldo@hotmail.com

${ }^{3}$ Centro de Energia Nuclear na Agricultura (CENA), Universidade de São Paulo (USP), Av. Centenário 303, Piracicaba, SP 13400-970, Brazil.

${ }^{4}$ Laboratório de Doenças Parasitárias, Departamento de Epidemiologia e Saúde Pública, Universidade Federal Rural de Rio de Janeiro (UFRRJ), BR 465 Km 7, Seropédica, RJ 23890-000, Brazil. E-mail: adivaldo@ufrrj.br
}

a representar um dos maiores problemas do sistema produção de herbívoros. 0 objetivo do estudo foi conhecer as populações de parasitos gastrintestinais e sua influência no ganho de peso em bezerros mantidos em sistemas orgânico e convencional. Para isso foram selecionados randomicamente bezerros orgânicos e convencionais durante os anos de 2008 e 2009. Através da contagem de ovos nas fezes (FEC) identificaram-se os seguintes gêneros de helmintos: Haemonchus, Trichostrongylus, Oesophagostomum, Cooperia, Strongyloides, Trichuris e Oocistos de Eimeria. Não foi observada diferença significativa $(p>0,05)$ entre a FEC nos animais orgânicos e convencionais. Animais com idade inferior a seis meses apresentaram infecção significativamente superior $(p<0,05)$ aos animais com 7-12 meses de idade. 0 ganho de peso observado durante o estudo foi de $327 \mathrm{~g} /$ dia e $280 \mathrm{~g} /$ dia para os animais dos sistemas convencional e orgânico, respectivamente. Assim, a combinação de práticas de manejo sustentáveis associadas a aplicação seletiva de anti-helmíntico pode ser a alternativa viável para 
o controle de nematóides para sistemas convencionais e de transição para o orgânico.

TERMOS PARA INDEXAÇÃO: Anti-helminticos, eimeriose, haemonchose, produção sustentável, cattle.

\section{INTRODUCTION}

Disease caused by internal parasites is arguably one of the most important health constraints affecting productivity in ruminants kept in organic and conventional system (Pruett et al. 2008, Silva et al. 2011, Chartier \& Paraud 2012). This is of particular importance for many tropical and subtropical countries where cattle, goats and sheep play a vital role in the agricultural economies (Jackson et al. 2012).

In Brazil, conventional system producers control helminths mostly by the intensive use of anthelmintic ingredients. Although these drugs are efficient, the lack of protocols adapted for tropical regions combined with the disorganized use of therapeutic bases have caused the cost of production increase (Larsson et al. 2007). These factors added to the existence of resistant breeds (Amarante et al. 2004), higher level of contamination from water and food providers, and presence of drug residues in meat and dairy products (Coppieters et al. 2009) already represent a significant threaten for the sustainability of both systems.

The first description of intestinal parasites in organic production systems was given by Thamsborg et al. (1999). Helminths have been considered to represent the greatest cause of economic losses regarding organic cattle (Kaneene \& Miller 1992). These losses have been exacerbated by the prohibition of anthelmintic treatment among such animals (Brasil 2011). Consequently, the prevalence of gastrointestinal nematodes in organically farmed animals tends to be higher than in conventional dairy herds.

Information about populations of nematodes in dairy cows and calves kept in organic production systems is scarce. Clearly, investigation on this topic is very important in order to clarify the epidemiology of these parasites in such systems (Höglund et al. 2010). Thus, the purpose of this study was to compare the evolution of parasitism level by helminths with weight gain in calves kept in organic and conventional systems.

\section{MATERIALS AND METHODS}

The organic system calves belonged to the herd of the Brazilian Organization for Agricultural Research (Embrapa Agrobiologia). The conventional system calves belonged to the Company of Agricultural Research of Rio de Janeiro (Pesagro-Rio). The experimental area is located in the metropolitan micro region of the city of Rio de Janeiro $\left(22^{\circ} 45^{\prime} \mathrm{S}\right.$ latitude, $43^{\circ} 41^{\prime} \mathrm{W}$ longitude, and 33 meters altitude). The calves were randomly selected to be monitored in the first grazing season, from January 2008 to December 2010.

Thirty calves were observed in the organic system every 15 days. The animals were crossbred (Bos taurus $\mathrm{x}$ Bos indicus) with blood level ranging from $1 / 2$ to $5 / 8$ B indicus. To handle food, 0 to 2-year-old calves were kept in crates in the stable only at night. During the day they were kept in grazing areas with Coast-cross grass (Cynodon dactylon L. Pers., Coastcross), subdivided into three areas of $60 \mathrm{~m}^{2}$ each, and handled in rotational system with 14 days of grazing and 28 days for resting.
Two to 6-month-old calves were kept in an area of 0.47 ha, composed by a grazing of African Star grass (Cynodon nlenfuensis, Vanderyst) with the following legumes: Pinto Peanut (Arachis pintoi), Desmondium (Desmodium ovalifolium), and Estylosanthes (Estylosanthes guyanensis), subdivided into 5 areas of $1175 \mathrm{~m}^{2}$, kept in rotational system with 8 days of grazing and 32 days for resting.

Six to 12-month-old calves grazed together with the remaining herd, composed by dry and lactating cows at a total of 31 animals in thus grazing. The total grazing area was 7.8 ha divided into seven areas of 1.3 ha, composed by Tanzania grass (Panicum maximum cv. Tanzânia) combined with Calopo (Calopogonium mucunoides). The grazing system used was the rotational one with 7 days of grazing, 42 days for resting, and occupation rate of $2 \mathrm{UA} / \mathrm{ha}^{-1}$ in the rainy period. The animals did not receive any chemical medicine for gastrointestinal worm control.

In Fall and Winter, in addition to the grass, 0 to 6-month-old calves were fed with Gliricidia hay (Gliciricia sepium), and the six to twelve months of age animals were fed with sugar cane (Saccharum officinarum) combined with Guandu (Cajanus cajan), and Elephant grass (Pennisetum purpureum Schum. cv. cameroon) with Siratro (Macropitilium atropurpureum) chopped daily into the feeder.

The calves were only weaned at 90 days of age according to the organic production legislation (Brazil 2008), and received 0.600 to $0.800 \mathrm{~kg}$ of concentrate per day (12\% PB and $66 \%$ NDT), produced with organic ingredients up to 6 years of age, being limited for the inducement of forage consumption of good quality. From 6 to 12 months of age, the concentrate amount went from 1 to $2 \mathrm{~kg} /$ day, as the grazing was done with adult animals.

Twenty-seven calves were kept in conventional system. The animals were crossbreed (B. taurus $\times$ B . indicus), with blood level ranging from $5 / 8$ to $7 / 8$ of $B$. taurus blood. After birth, the calves were kept with the cows just long enough to ingest the colostrum. Then, the calves were kept in individual crates during the first 15 days of life, receiving $4 \mathrm{~kg}$ of milk/animal/day. From 15 to 120 days of age the calves were kept in an area of 0.40 ha of a Brachiaria humidicula pasture. After that, the animals were transferred to the heifer sector, where all animals from the herd, with 4 to 12 months of age, were kept. In that area, the animals were grazing in a Brachiaria humidicula pasture, receiving $2 \mathrm{~kg} /$ animal/day of commercial food with $22 \%$ of crude protein and mineral salt.

In the conventional system, anthelmintic prophylaxis was administered once a month. The active ingredient used was Ivermectin $(0.2 \mathrm{mg} / \mathrm{kg})$ single dosage shot. Faecal samples were taken directly from the rectum of the calves for fecal egg count (FEC) using a modified McMaster technique. Composite cultures were performed for each infected group. The larvae obtained were identified according to the description of Keith (1953). To monitor the weight gain of the animals, the calves from both systems were weighted in the first 24 hours after birth and at 120, 180, 240 and 365 days of age.

For the statistical analysis, the data from FEC were first subjected to the normality test (Kolmogorov-Smirnov) to ascertain whether the data conformed to normal distribution. Because the data did not show normal distribution even after logarithmic transformation to $\log _{10}(x+1)$, comparisons were made between averages by applying the Kruskal-Wallis test at 5\% significance. The generalized linear model methodology was used, assuming Poisson distribution with a logarithmic link function. The operational procedures were done using the R Foundation statistical computing software, version 2.12.2 (2011). 


\section{RESULTS}

The average values and standard deviations of the helminth eggs count of Trichostrongyloidea and Strongyloidea super family, in feces of calves kept in organic and conventional production system during the first grazing season, are found in Figure 1.

The level of infection in calves from the organic system ranged from moderate to heavy, being the higher FEC observed in February (800 EPG). In the conventional system, the infection ranged from light to heavy, being the higher FEC in May (1300 EPG). Thus, there was a significantly difference $(p<0.05)$ between the parasite load of organic and conventional systems animals only in February and May. In the other months, both groups presented similar parasite profile.

In organic system animals, there was no statistical difference $(p>0.05)$ in FEC due to the season of the year. However, in conventional system the infection was higher ( $p>0.05$ ) in the fall. In the comparison between each other, in the winter, spring, and summer there was no significant difference ( $p>0.05)$, while in fall the conventional animals showed more parasitism $(\mathrm{p}<0.05)$.

Among the fecal samples from organic system animals, $47 \%$ showed egg counts below 350 EPG, 33\% between 350 and $500 \mathrm{EPG}$, and $20 \%$ higher than $500 \mathrm{EPG}$. In this system, the higher individual value observed was 3000 EPG in February. Among the conventional animals, 50\% showed egg elimination below $3000 \mathrm{EPG}, 10 \%$ between 350 and 500 $\mathrm{EPG}$, and $40 \%$ above $500 \mathrm{EPG}$. In this system, the higher individual level was 500 EPG in May.

When the age was evaluated as a risk factor to the occurrence of worms, the study observed that FEC in animals aged up to 6 months of age was higher $(\mathrm{p}<0.05)$ than in 6 to 12 -month-old animals, both in organic and conventional system (Fig.2). In the comparison between production systems, the parasite load in animals aged 0 to 6 years of age and 6 to 12 years of age did not show statistical difference $(\mathrm{p}>0.05)$.

In the organic system, $60 \%$ of animals aged 0 to 12 months showed egg count higher than $500 \mathrm{EPG}$, while it was only $20 \%$ in 6 to 12 -month-old animals. In the conventional system, nearly $48 \%$ of the animals younger than 6 month of age showed egg elimination higher than 500 EPG in comparison to only $13 \%$ of the animals older than 6 months old.

The most prevalent helminths belonged to Trichostrongylus and Oesophagostomum genders, the percent values were equal between both production systems. Nearly $70 \%$ of the identified larvae were from Haemonchus spp. gender. During the dry season of the year (fall and winter), a significant increase $(p<0.05)$ in the number of Trichostrongylus spp. was observed, as well as reduction in the number of Haemonchus. In the same period, there was no alteration in the number of Oesophagostomum larvae. The Cooperia gender was observed only in some samples and still in low prevalence $(<3 \%)$.

During the whole study, the animals kept in conventional system showed higher elimination $(\mathrm{p}<0.05)$ of Strongyloides papillosus eggs in comparison to animals kept in organic system. The conventional animals showed FEC

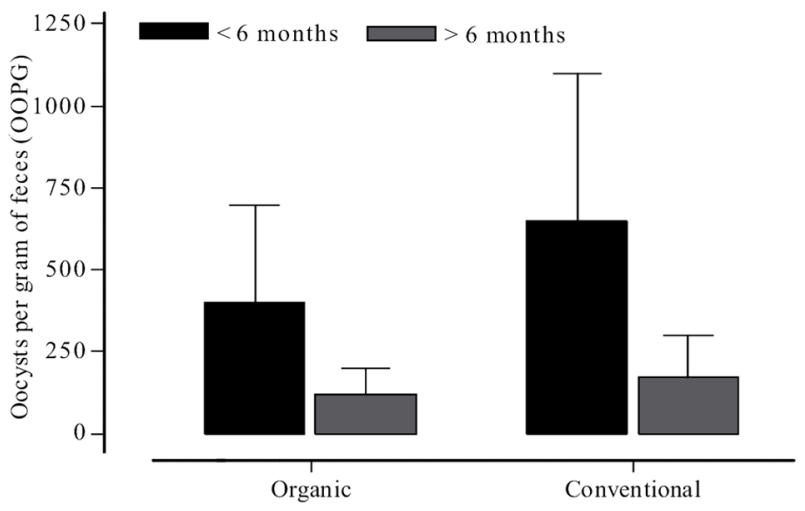

Fig.1. Mean value and standard deviation of helminth egg counts (Trichostrongyloidea superfamily) in feces of calves younger than 6 months and in 6 to 12-month-old calves, kept in the organic production system (Embrapa Agrobiologia) and in the conventional one (Pesagro-Rio), Seropédica, RJ, 2008/009.

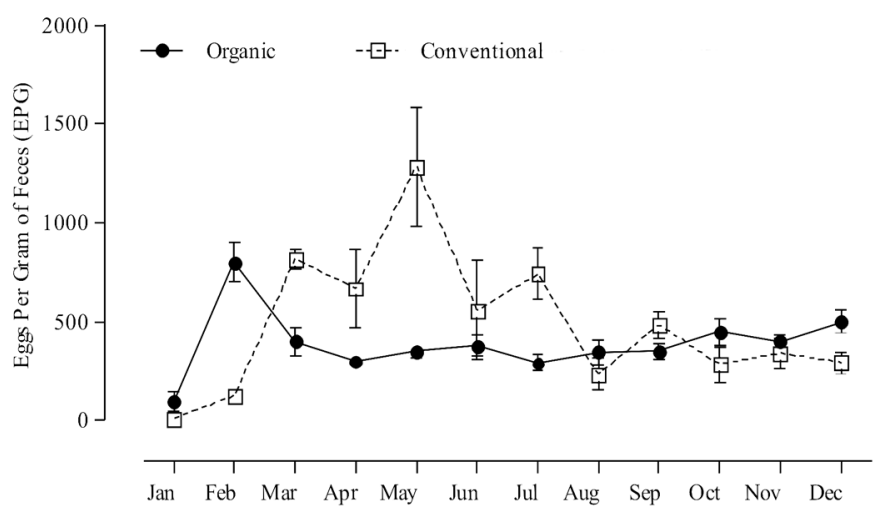

Fig.2. Mean value and standard deviation of helminth egg counts (Trichostrongyloidea superfamily) in feces of calves younger than 6 months and in 6 to 12-month-old calves, kept in the organic production system (Embrapa Agrobiologia) and in the conventional one (Pesagro-Rio), Seropédica, RJ, 2008/2009.

below $490 \mathrm{EPG}$, while in organic animals the counting was below 300 EPG. When the parasite load was evaluated according to age, it was noticed higher parasitism $(p>0.05)$ in animals younger than four months of age in both production systems.

Not only in organic system animals but also in conventional ones, a higher egg count of $S$. papillosus eggs was observed in May. In this month, the higher individual elimination of eggs was 1500 EPG in a conventional animal, and 900 in an organic one. Starting from 9 months of age, all animals showed stabilization in egg elimination, being always below to $180 \mathrm{EPG}$.

The egg counting of Trichuris were low. Nearly $50 \%$ of the organic samples showed 0 EPG, 35\% between 0 and $100 \mathrm{EPG}$, and 15\% higher than $100 \mathrm{EPG}$. Among these animals, the higher individual counting of eggs was 400 EPG. In conventional animals, $70 \%$ showed $0 \mathrm{EPG}, 25 \%$ between 0 and $100 \mathrm{EPG}$, and 5\% above $100 \mathrm{EPG}$. The higher value of individual EPG was observed in an organic animal in $\mathrm{Au}$ gust (600 EPG).

The oocysts counting of Eimeria spp. did not show significant difference ( $p>0.05$ ) between the organic and conventional animals, except in April when the infection in con- 
ventional animals was significantly $(p<0,05)$ higher than in organic animals (Fig.3).

In the entire first year of grazing, the average counting of Eimeria spp. was below 400 EPG in both groups of animals, except in April in which the average value was 800 EPG for conventional animals. The higher individual value of oocysts counting was observed in April, when a conventional animal showed 3000 EPG.

The weight at birth, at six and twelve months of age animals kept in organic and conventional systems, is represented below (Table 1). The weight gain of animals at 7 months of age was $92.7 \mathrm{~kg}(515 \mathrm{~g} /$ day) in conventional animals, and $81.0 \mathrm{~kg}\left(450 \mathrm{~g} /\right.$ day) in the organic ones. From the $7^{\text {th }}$ to the $12^{\text {th }}$ month, a weight gain of $25.0 \mathrm{~kg}(140 \mathrm{~g} /$ day $)$ was observed for conventional animals, and $20 \mathrm{~kg}(110 \mathrm{~g} /$ day $)$ for organic animals. Thus, from the birth to 12 months of age, the average weight gain observed was $107.8(327 \mathrm{~g} /$ day $)$ in animals kept in conventional system, and $100.5 \mathrm{~kg}(280 \mathrm{~g} /$ day) in organic animals.

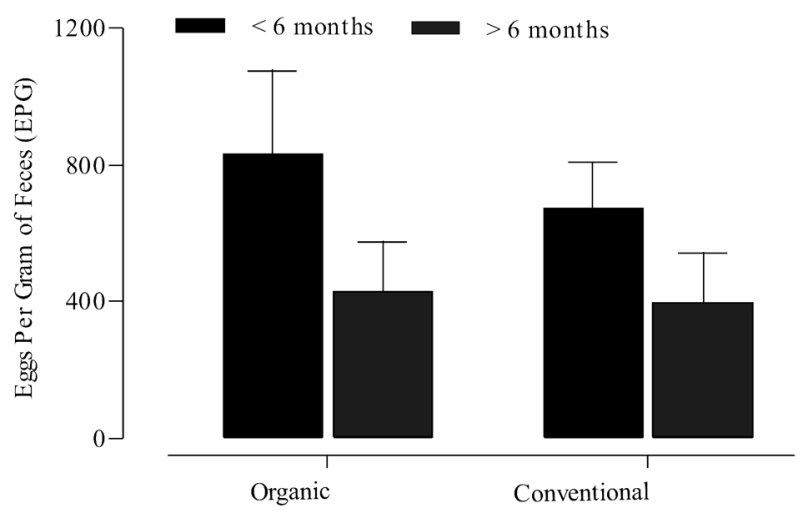

Fig.3. Average and standard deviation of the oocyst counts of Eimeria spp. in the feces of calves during the first grazing season, kept in the organic production system (Embrapa Agrobiology) and in the conventional one (Pesagro-Rio), Seropédica, RJ, $2008 / 2009$.

Table 1. Study of the production variables, birth weight and weight gain in calves maintained in the organic production system (Embrapa Agrobiology) and in the conventional one (Pesagro-Rio), Seropédica, RJ, 2008/2009.

\begin{tabular}{|c|c|c|c|}
\hline \multicolumn{4}{|c|}{$\begin{array}{c}\text { Evaluation of weight gain }(\mathrm{kg}) \text { in calves kept on organic and } \\
\text { conventional system }\end{array}$} \\
\hline Production system & Birth & Six months & Twelve months \\
\hline Conventional & $32.2 \pm 3.4$ & $125 \pm 13.8$ & 13.7 \\
\hline Organic & $29.5 \pm 2.0$ & $110 \pm 7.8$ & $130 \pm 9.0$ \\
\hline
\end{tabular}

\section{DISCUSSION}

In this study, the grazing practices used in organic system and the use of anthelmintics in conventional system was efficient for the control of helminth diseases. Although the animals were infected during the entire study, there were no sick animals. Ploeger et al. (2000) observed a tendency of super protection of calves in conventional system. This practice, according to Vercruysse \& Claerebout (2001), may be catastrophic, because it creates an improper development of the immune system acquired by the animals through lack of permanent contact with helminths.
The results observed in this study corroborate with Höglund et al. (2001), who noticed levels of infection ranging from low to moderate in organic calves of first grazing. Höglund et al. (2001) linked the low parasite load of the animals to the handling practices, such as grazing resting, low animal density, and nutritional supplementation.

Lima (1998) demonstrated that gastrointestinal nemathelmints may infect animals of any age; however, the problem was more severe in young animals. In this study, although the animals were infected during the whole study, it was noticed that age is a risk factor for helmintic disease, once until 6 months of age the animals must be more carefully monitored as this period is critical for occurrence of the disease. In Europe, Shaw et al. (1998) observed that at 56 days after birth, the calves showed FEC higher than $200 \mathrm{EPG}$, with frequent outbreaks of the disease. In this study, animals kept in organic system showed egg elimination above $200 \mathrm{EPG}$, from 30 days of age on. In conventional animals, it happened from 60 days of age.

We observed that among the species that infect calves, gender Haemonchus was the more spreading one. Pimentel Neto \& Fonseca (2002), studying the prevalence of Haemonchus, observed that the parasite directly influences the productive performance of the herd, according to the age group with intensity of infection and low nutritional state of animals. These same authors observed that moderate infection levels, when Haemonchus is the predominant helminth, cause usually mortality in young animals. In this study, no mortality was observed due to the presence of Haemonchus, probably because the level of animal parasitism was not constantly high.

The results of this study concerning Stronyloides papillosus corroborate with Pimentel Neto \& Fonseca (2002) and Jimenez et al. (2010) who, while studying gastrointestinal parasites in calves, noticed low prevalence of this agent among the animals. However, the high incidence of $S$. papillosus in calves until 4 months of age is mainly related to trans-cutis infection (Jimenez et al. 2010). Concerning Trichuris gender, the results of the present study were close to the ones observed by Jimenez et al. (2010) who verified frequency of 7.8 to $14.5 \%$. These same authors observed high parasite load in only $10 \%$ of the animals. The lack of clinical signs noticed in this our study may be related to the handling of young animals (Keyyu et al. 2006).

The elimination of Eimeria oocysts by animals in both systems was similar to the one observed by Höglund et al. (2001). These authors did not notice any clinical case of coccidiosis, and justified the results with the grazing handling and the nutritional state of the animals. In this our study, the young animals were kept apart from the adult ones, aiming to avoid the calves' infection by oocysts constantly eliminated by adult animals.

Thamsborg (2001), studying the population of gastrointestinal parasites in calves, observed that animals kept in organic system showed higher elimination of oocyst in feces than conventional animals. These same authors noticed that eimeriosis is a serious problem in organic farms, once $14 \%$ of the organic herds showed diarrhea, and only $6 \%$ in conventional system. Thus, infections with endoparasites 
may represent a problem in the production of organic milk, but the variation among the farms is considerable. Most problems are related to calves younger than 3 months, without food supplementation, good quality grazing, and use of grazing rest procedures (Thamsborg 2001).

Many studies have associated the subclinical infection to the low weight gain (Borgsteede et al. 1985, Shaw et al. 1998). This study considered that the use of anthelmintics in animals kept in conventional system may be responsible for average gain of $17.3 \mathrm{~kg} /$ year ( $47 \mathrm{~g} /$ day), more than animals kept in organic system and anthelmintic free. Shaw et al. (1998) observed weight gain of $40 \mathrm{~g} /$ day in animals with subclinical infection and not treated with chemotherapeutics during the first grazing season. On the other hand, animals treated with anthelmintics demonstrated significantly higher weight gain, about $160 \mathrm{~g} /$ day (Shaw et al. 1998). In this our study, this difference was observed as well, but without statistical difference.

\section{CONCLUSIONS}

The present study indicates that worm infection is a parasitic disease problem in organic and conventional dairy herds of the farm studied.

It also shows that gastrointestinal parasites may be kept on low to moderate levels through good management and without prophylactic anthelmintic treatment.

The management practices adopted in the organic production system were efficient for the control of helminth infection.

In contrast, monthly applications of anthelmintics were not efficient to combat helminths.

Conventional herds were more likely to use intensive grazing, what may have accounted for their higher rate of gastrointestinal nematodes as compared with organic herds.

Better knowledge about the effects of strategic nutritional supplementation on the level of parasitism needs to be accomplished through further experimentation.

Acknowledgments.- To the National Council for Scientific and Technological Development (CNPq), and to the Co-ordination for Improvement of Higher Education Staff (CAPES) for the financial support. To the Empresa de Pesquisa Agropecuarioa do Estado do Rio de Janeiro (Pesagro-Rio) and Empresa Brasileira de Pesquisa Agropecuaria (Embrapa agrobiology) for providing the animals for the study.

\section{REFERENCES}

Amarante A.F.T., Bricarello P.A., Rocha R.A. \& Gennari S.M. 2004. Resistance of Santa Ines, Suffolk and Ile de France lambs to naturally acquired gastrointestinal nematode infections. Vet. Parasitol. 120:91-106.

Borgsteede F.H., Kloosterman A., Oostendorp D. \& Van Tarrij H. 1985. Effects of the use of a morantel sustained release bolus in first and second year grazing cattle. Vet. Parasitol. 18:39-49.

Brasil 2011. Legislação para os sistemas orgânicos de produção animal e vegetal. Secretaria de Desenvolvimento Agropecuário e Cooperativismo, Ministério da Agricultura, Pecuária e Abastecimento (MAPA/ACS), Brasília. 195p.
Chartier C. \& Paraud C. 2012. Coccidiosis due to Eimeria in sheep and goats: a review. Small Rumin. Res. 103:84-92.

Coppieters W., Mes T.H.M., Druet T., Farnir F., Tamma N., Schrooten C., Cornelissen A.W.C.A., Georges M. \& Ploeger H.W. 2009. Mapping QTL influencing gastrointestinal nematode burden in Dutch Holstein-Friesian dairy cattle. BMC Genom. 10:96-109.

Höglund J., Svensson C. \& Hessle A. 2001. A field survey on the status of internal parasites in calves on organic dairy farms in southwestern Sweden. Vet. Parasitol. 99:113-128.

Höglund J., Dahlströmb F., Engströmb A., Hessleb A., Jakubeka E., Schniederc T., Strubec C. \& Sollenberga S. 2010. Antibodies to major pasture borne helminth infections in bulk-tank milk samples from organic and nearby conventional dairy herds in south-central Sweden. Vet. Parasitol. 171:293-299.

Jackson F., Varady M. \& Bartley D.J. 2012. Managing anthelmintic resistance in goats: can we learn lessons from sheep? Small Rumin. Res. 103:3-9.

Jimenez A.E., Fernandez A., Alfaro R., Dolz G., Vargas B., Eped C. \& Schniedere T. 2010. A cross-sectional survey of gastrointestinal parasites with dispersal stages in feces from Costa Rican dairy calves. Vet. Parasitol. 173:236-246.

Kaneene J.B. \& Miller R. 1999. Description and evaluation of the influence of veterinary presence on the use of antibiotics and sulfonamides in dairy herds. J. Am. Vet. Med. Assoc. 201:68-76.

Keith R.K.1953. The differentiation of the infective larvae of some common nematode. Aust. J. Zool. 1:223-235.

Keyyu J.D., Kassuku A.A., Msalilwa L.P., Monrad J. \& Kyvsgaard N.C. 2006. Cross-sectional prevalence of helminth infections in cattle on traditional, small-scale and large-scale dairy farms in Iringa District, Tanzania. Vet. Res. Commun. 30:45-55.

Larsson A., Dimander S.O., Waller A., Uggla A. \& Höglund J. 2007. A 3-year field evaluation of pasture rotation and supplementary feeding to control parasite infection in first-season grazing cattle: dynamics of pasture infectivity. Vet. Parasitol. 145:129-137.

Lima W.S. 1998. Seasonal infection pattern of gastrointestinal nematodes of beef cattle in Minas Gerais state, Brazil. Vet. Parasitol. 74:203-214.

Pimentel Neto M. \& Fonseca A.H. 2002. Epidemiologia das helmintoses pulmonares e gastrintestinais de bezerros em região de baixada do Estado do Rio de Janeiro. Pesq. Vet. Bras. 22:148-152.

Ploeger H.W., Borgsteede F.H., Sol J., Mirck M.H., Huyben M.W., Kooyman F.N. \& Eysker M. 2000. Cross-sectional serological survey on gastrointestinal and lung nematode infections in first and second-year replacement stock in the Netherlands: relation with management practices and use of anthelmintics. Vet. Parasitol. 90:285-304.

Shaw D.J., Vercruysse J., Claerebout E. \& Dorny P. 1998. Gastrointestinal nematode infections of first-grazing season calves in Western Europe: general patterns and the effect of chemoprophylaxis. Vet. Parasitol. 75:115-131.

Silva J.B., Fagundes G.M. \& Fonseca A.H. 2011. Dynamics of gastrointestinal parasitoses in goats kept in organic and conventional production systems in Brazil. Small Rumin. Res. 98:35-38.

Thamsborg S.M., Roepstorff A. \& Larsen M. 1999. Integrated and biological control of parasites in organic and conventional production systems. Vet. Parasitol. 84:169-186.

Thamsborg S.M. 2001. Organic farming in the Nordic countries: animal health and production. Acta Vet. Scand. 43:7-15.

Vercruysse J. \& Claerebout E. 2001. Treatment vs non-treatment of helminth infections in cattle: defining the threshold. Vet. Parasitol. 98:195214.

Weller R.F. \& Bowling P.J. 2000. Health status of dairy herds in organic farming. Vet. Rec. 146:80-81. 